\title{
Evaluation of the potential of the common cockle (Cerastoderma edule L.) for the ecological risk assessment of estuarine sediments: bioaccumulation and biomarkers
}

\author{
Jorge Lobo • Pedro M. Costa • Sandra Caeiro • \\ Marta Martins • Ana M. Ferreira - Miguel Caetano • \\ Rute Cesário · Carlos Vale • Maria H. Costa
}

Accepted: 4 August 2010/Published online: 18 August 2010

(C) Springer Science+Business Media, LLC 2010

\begin{abstract}
Common cockles (Cerastoderma edule, L. 1758, Bivalvia: Cardiidae) were subjected to a laboratory assay with sediments collected from distinct sites of the Sado Estuary (Portugal). Cockles were obtained from a mariculture site of the Sado Estuary and exposed through 28-day, semi-static, assays to sediments collected from three sites of the estuary. Sediments from these sites revealed different physico-chemical properties and levels of metals and organic contaminants, ranging from unimpacted (the reference site) to moderately impacted, when compared to available sediment quality guidelines. Cockles were surveyed for bioaccumulation of trace elements $(\mathrm{Ni}$, $\mathrm{Cu}, \mathrm{Zn}, \mathrm{As}, \mathrm{Cd}$ and $\mathrm{Pb}$ ) and organic contaminants (PAHs, PCBs and DDTs). Two sets of potential biomarkers were employed to assess toxicity: whole-body metallothionein (MT) induction and digestive gland histopathology. The bioaccumulation factor and the biota-to-soil accumulation factor were estimated as ecological indices of exposure to metals and organic compounds. From the results it is inferred that $C$. edule responds to sediment-bound contamination and might, therefore, be suitable for biomonitoring.
\end{abstract}

J. Lobo $(\bowtie) \cdot$ P. M. Costa $\cdot$ S. Caeiro $\cdot$ M. H. Costa

IMAR-Instituto do Mar, Departamento de Ciências e Engenharia do Ambiente, Faculdade de Ciências e Tecnologia da Universidade Nova de Lisboa, 2829-516 Monte de Caparica, Portugal

e-mail: j.arteaga@fct.unl.pt

S. Caeiro

Departamento de Ciências Exactas e Tecnológicas, Universidade Aberta, Rua da Escola Politécnica, 141, 1269-001 Lisbon, Portugal

M. Martins - A. M. Ferreira - M. Caetano · R. Cesário · C. Vale IPIMAR-INRB, Instituto Nacional dos Recursos Biológicos, Avenida de Brasília, 1449-006 Lisbon, Portugal
The species was found capable to regulate and eliminate both types of contaminants. Still, the sediment contamination levels do not account for all the variation in bioaccumulation and MT levels, which may result from the moderate metal concentrations found in sediments, the species' intrinsic resistance to pollution and from yet unexplained xenobiotic interaction effects.

Keywords Cerastoderma edule - Sado estuary · Sediment contaminants - BAF and BSAF . Metallothionein · Histopathology

\section{Introduction}

Marine bivalve mollusks are mainly sedentary filter-feeders characterised by their very high capability to bioaccumulate chemical substances dissolved in the water or bound to suspended particles (Machreki-Ajmi et al. 2008; Solé et al. 2009). These substances can be organic compounds or metallic elements (essential or not), both with potential to cause toxic effects. Due to their fast response to environmental changes, bivalves are therefore considered good bioindicators for the assessment of environmental quality (Cajaraville et al. 2000; Hédouin et al. 2007).

The assessment of polluted environments based only on chemical analyses is difficult, particularly the assessment of polluted sediments due to the complex nature of the sediment matrix and the potential for exposure of aquatic organisms to in-place contaminants via several routes (Del Valls et al. 1998). For such reasons, the use of biomarkers has been considered to provide reliable measures of the impact of toxicity (Huggett et al. 1992; Peakall and Shugart 1993). In recent years, biomarkers that may provide information on the effects of xenobiotics in organisms have 
received considerable attention and many of them have been validated in bivalves, such as, for instance, metallothionein induction and oxidative stress-related enzymes (Geret et al. 2003; Bergayou et al. 2009). Mussels and oysters are the marine bivalves most often used in pollution monitoring. However, other species have been studied because of their importance for human consumption or their close contact with sediment (Amiard et al. 2006). Some of these species have been widely employed for toxicity assessment and biomarker techniques have already been validated (Livingstone 2001; Solé et al. 2009). Translocation of bivalves between areas with different levels of water and sediment contamination has long been employed for standard biomonitoring of aquatic ecosystems. These procedures have been proved to provide valuable information on the mollusks' responses and defences against contamination, with especial respect to the kinetics of xenobiotic uptake and elimination (see De Kock and Kramer 1994, for a thorough review).

The common cockle (Cerastoderma edule, Bivalvia: Cardiidae) is widely distributed from north-east Norway to West Africa. It lives buried in the few upper centimeters of the sediment, frequently exhibiting high populational densities, in marine and estuarine environments. High inter-individual variability of reproduction stage, parasite load, metallothionein (MT) concentration, etc. is generally observed in C. edule populations (Baudrimont et al. 2006). It is highly tolerant to environmental variations of physicochemical parameters such as sediment grain size and salinity, and may thus be employed as an indicator organism along an estuarine gradient. In the Sado Estuary, for instance, this cockle colonizes all intertidal sediments, from the sand beach of Tróia Peninsula close to the estuarine mouth to the mudflats in the channel of Águas de Moura located upstream. C. edule has been tested in recent toxicological studies (e.g. Jung et al. 2006) but despite its characteristics, there are very few ecotoxicological studies with this bivalve.

The response to sediment-bound contamination and the capability to regulate and eliminate both organic and metallic contaminants are reflected in biomarkers, as MT induction and histopathological alterations. Metallothioneins are small cytosolic proteins involved in metal accumulation, transport and elimination. In many bivalves, MT induction has been linked to increased levels of pollution (Marie et al. 2006; Serafim and Bebianno 2009). Histopathological lesions in bivalves have already been related to soft-tissue concentrations of contaminants (Gold-Bouchot et al. 1995). In general, the gills and digestive glands are, in mollusks, the major target organs for pollution studies (Gold-Bouchot et al. 1995; Syasina et al. 1997; Zaldibar et al. 2007, 2008). Still, histopathology studies in C. edule are absent.
The Sado Estuary, located on the west coast of the Iberian Peninsula, is the second largest in Portugal with an area of approximately 24,000 ha. The estuary comprises the Northern and the Southern Channels, partially separated by intertidal sandbanks. Water exchange is conducted mainly through the Southern Channel, which reaches a maximum depth of $25 \mathrm{~m}$, whereas the maximal depth of the Northern Channel is generally $10 \mathrm{~m}$. Part of the estuary is classified as a natural reserve, with a weighty ecological and landscape value. The region equally plays an important role for leisure and recreation, and therefore is important for the local and national economies. The city of Setúbal located in the North edge of Sado Estuary, has a large resident population and an important heavy-industry in the adjacent area. The estuary is an important fishing area and many aquaculture facilities have been settled during the past few years. The southernmost section of the estuary is mainly characterized by an important tourism-based economy. The major sources of anthropogenic contaminants are mainly the pyrite mines along the river basin; the industries that produce paper pulp, pesticides, fertilizers, animal feeds; the shipyards along the north shore of the lower estuary and the runoffs from extensive agriculture grounds located upstream, besides urban discharges from the city of Setúbal, heavy shipping and a thermoelectrical power plant. The results of previous studies indicate that anthropogenic sources play a major role on the elemental composition of the Sado estuarine sediments (Cortesão and Vale 1995). Still, the estuary has a low contamination level with some local hotspots and a moderate potential for observing adverse biological effects (Caeiro et al. 2005).

The present work intends to evaluate effects and responses to sediment-bound metallic and organic toxicants in mariculture-brooded $C$. edule and to investigate the species' potential as an indicator organism by simulating sediment translocation assays under controlled laboratory conditions to minimize environmental background noise. Specifically, this study was aimed (i) to analyze two sets of different biomarkers, MT induction and histopathological alterations, yet little investigated in bivalves; (ii) to assess bioaccumulation through a bioaccumulation factor approach to allow integration of data with sediment parameters and (iii) to relate the cockles' responses to the physico-chemical characteristics of the tested sediments and also the cockles' mariculture sediment.

\section{Materials and methods}

\section{Experimental assay}

The tested sediments were collected with a dredge from three different sites (S1, S2, and S3) of the Sado Estuary 
(Fig. 1) on November 2006, selected on the basis of their potentially different levels of metallic and organic contamination. Site S1 (the reference site) is located near an environmentally protected area (the Sado Estuary Natural Reserve) and is the most distant from sources of contamination. Due to its location in the south channel of estuary, this site is more influenced by oceanic hydrodynamism and has lower water residence time (Caeiro et al. 2005). Site S2 is located near the port of Setúbal and site S3 in the industrial zone near factories for the production of fertilizers, pesticides and others (such as paper mill, a thermoelectric power plant, shipyards, etc.), identified as potential sources of pollution (Caeiro et al. 2005). Sites S2 and S3 are both located in areas of low hydrodynamism, which facilitates the retention of contaminants and fine particles of sediment from the upper estuary. The cockles were cultured and collected from a distinct site (site CS), located near aquaculture and small-scale fishery grounds, consisting of a confined area with low hydrodynamism. Site CS is the only one located in the intertidal zone and is also the only located inside the Natural Reserve Protected Area and distant from local pollution sources; all the other sites ( $\mathrm{S} 1$, S2 and S3) are located in the subtidal zone.

Cockles $(28 \pm 1.6 \mathrm{~mm}$ shell length, $8.0 \pm 1.4 \mathrm{~g}$ wholebody wet weight $[\mathrm{ww}]$ ) were collected on November 2006 and acclimatized to laboratory conditions (temperature of $18^{\circ} \mathrm{C}$ and salinity of 34) in clean sand and seawater for $48 \mathrm{~h}$. The bivalves were exposed to the sediments (S1, S2 and S3) directly after collection for 28 days through a semi-static arrangement of bioassays (performed in

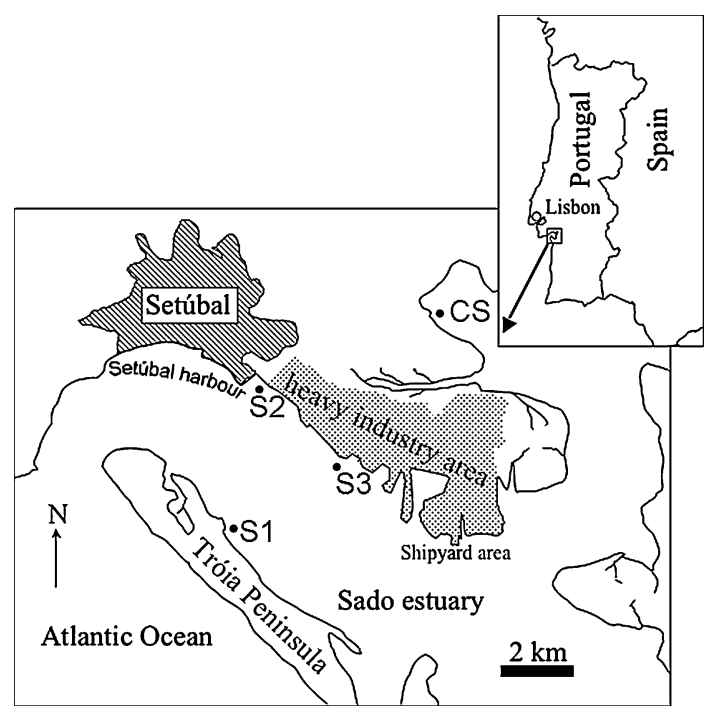

Fig. 1 Map of the study area showing the sediment collection sites $(\bullet)$. Site $S 1$ is the reference (relatively unpolluted) site, whereas $S 2$ and $S 3$ are contaminated. Site $C S$, located in important mariculture and fishing areas of the estuary, is the cockle culture site duplicate). Each replicate consisted of a tank $(24 \times 11 \times$ $39 \mathrm{~cm}$ ) with 21 of sediment and 51 of clean seawater. Forty randomly-selected animals were distributed per tank. Aeration was continuous and set to avoid sediment disturbance. The animals were fed daily with pulverized commercial fish food. Salinity, dissolved oxygen, ammonia, $\mathrm{pH}$ and temperature were monitored weekly. A $50 \%$ water change was enforced on a weekly basis to ensure constancy of water parameters with minimum removal of xenobiotics. The animals were collected and sacrificed for analysis at days, 14 (T14) and 28 (T28) in order to determine the bioaccumulation of metallic and organic contaminants, metallothionein induction and histopathological alterations of the digestive gland. For each test and sampling time, 20 individuals were used to determine the organic contaminants, 10 individuals to determine the metals and metallothioneins and 10 to examine the histopathology. Animals collected at T0 consisted of 15 individuals collected directly from the acclimatization tanks and should reflect the conditions of the culture site, CS.

Sediment analyses

\section{Physico-chemical characterization}

Sediment redox potential (Eh) was measured immediately after collection, using an Orion model 20A meter with a $\mathrm{H} 3131 \mathrm{Pt}$ electrode and a $\mathrm{Ag} / \mathrm{AgCl}$ reference electrode (Orion Research Inc.). For the determination of the organic matter, the sediment was previously dried at $60-80^{\circ} \mathrm{C}$ and combusted at $500 \pm 25^{\circ} \mathrm{C}$ for $4 \mathrm{~h}$. The content of organic matter (extrapolated from total combustible carbon, TOM) is given in percent sediment dry weight (dw). Fine fraction (particle size $<63 \mu \mathrm{m}$ ) was determined by sieving after treating the samples with hydrogen peroxide and disaggregation with pyrophosphate.

\section{Contaminant determination}

The sediments were analysed for the metals nickel (Ni), copper $(\mathrm{Cu})$, zinc $(\mathrm{Zn})$, cadmium $(\mathrm{Cd})$ and lead $(\mathrm{Pb})$ and for the metalloid arsenic (As). Sediment samples $\left(\approx 100 \mathrm{mg} \mathrm{dw}\right.$ ) were mineralized completely with $6 \mathrm{~cm}^{3}$ of $\mathrm{HF}(40 \%)$ and $1 \mathrm{~mL}$ of Aqua Regia $(36 \% \mathrm{HCl}: 65 \%$ $\left.\mathrm{HNO}_{3} ; 3: 1\right)$ in closed Teflon vials at $100^{\circ} \mathrm{C}$ during $1 \mathrm{~h}$. Contents were evaporated to near dryness redissolved in $1 \mathrm{~mL}$ of $\mathrm{HNO}_{3}$ and $5 \mathrm{~mL}$ of Milli-Q water, heated for $20 \mathrm{~min}$ at $75^{\circ} \mathrm{C}$ and diluted to $50 \mathrm{~mL}$ with Milli-Q grade ultrapure water (Caetano et al. 2007). The metal concentrations were determined in a Thermo Elemental XSeries quadropole ICP-MS (inductively coupled plasma mass 
spectrometer) equipped with a Peltier Impact bead spray chamber and a concentric Meinhard nebulizer. MESS-2, PACS-2 and MAG-1 were the reference materials used to validate the procedure and were found within the certified range. Results are given in $\mathrm{mg} \mathrm{kg}^{-1}$ sediment $\mathrm{dw}$.

The determination of PAHs (polycyclic aromatic hydrocarbons) was performed on a GCQ Trace Finnigan gas chromatography-mass spectrometry (GC-MS) system with a $30 \mathrm{~m} \times 0.25 \mathrm{~mm} \times 0.25 \mu \mathrm{m}$ film thickness DB-5 MS column (Argilent, USA) in selected ion mode (Martins et al. 2008). Seventeen three- to six-ring PAHs were quantified. For PCB (polychlorinated biphenyls) and DDT (dichloro-diphenyl-trichloroethane) plus metabolites analyses, dry sediment samples were Soxhlet extracted with $n$-hexane for $16 \mathrm{~h}$. The extracts were cleaned up with Florisil and sulfuric acid (Ferreira et al. 2003). Eighteen PCB congeners and DDTs ( $p p D D D, p p D D E$ and $p p D D T$ ) were analysed by GC-MS using a Hewlett-Packard 6890 apparatus. The SMR 1941b reference sediment (NIST, USA) was used to validate the analysis and the results were found within the certified range. The detection limit was $0.01 \mathrm{ng} \mathrm{g}^{-1}$. All concentrations are expressed in $\mathrm{ng} \mathrm{g}^{-1}$ sediment dw.

The probable effects level quotient (PEL-Q) was calculated to evaluate the potential for observing adverse biological effects of the tested sediments. This quotient is based on the published guideline values for coastal waters, namely the threshold effects level (TEL) and the probable effects level (PEL; MacDonald et al. 1996). These guidelines have been largely used in estuarine sediment ecological risk assessment studies. This index was calculated for all contaminants of each sediment as given by the formula (Long and MacDonald 1998):

PEL $-Q_{i}=\frac{C_{i}}{\text { PEL }}$

where PEL is the guideline value for the contaminant $i$ and $\mathrm{C} i$ the measured concentration of the contaminant in the surveyed sediment. The sediment quality guideline quotient (SQG-Q) was calculated to compare the four sites impacted by mixtures as described by Long and MacDonald (1998):

$\mathrm{SQG}-\mathrm{Q}=\frac{\sum_{i=1}^{n} \mathrm{PEL}-\mathrm{Q}_{i}}{n}$

where PEL-Q $i$ is the index deriving from (1) for the contaminant $i$ and $n$ the number of contaminants under analysis. Stations were scored according to the overall potential of sediments to produce adverse biological effects, as proposed by MacDonald et al. (2004): SQG-Q $<0.1$ - unimpacted; $0.1 \leq \mathrm{SQG}-\mathrm{Q}<1$ - moderately impacted; SQG $\geq 1$ - highly impacted.
Organism analyses

\section{Bioaccumulation}

For the analysis of metals, whole soft-body individual samples $(0.025 \pm 0.003 \mathrm{~g} \mathrm{dw})$ were dried in borosilicate, lead free, glass vials at $60^{\circ} \mathrm{C}$ for 5 days and then digested in Teflon vials by adding $5 \mathrm{ml} 65 \%$ nitric acid and incubated for $24 \mathrm{~h}$ at room temperature. The vials were then placed in a water bath at $95^{\circ} \mathrm{C}$ during $4 \mathrm{~h}$, after which $1 \mathrm{ml}$ hydrogen peroxide $(30 \% \mathrm{v} / \mathrm{v})$ was added, followed by another hour at $95^{\circ} \mathrm{C}$ in a water bath (Clesceri et al. 1999). Finally, the samples were stored in HDPE plastic bottles after elution with Milli-Q water and kept at $4^{\circ} \mathrm{C}$ until element quantification. The quantification of trace elements (Ni, $\mathrm{Cu}, \mathrm{Zn}, \mathrm{Cd}, \mathrm{Pb}$ and $\mathrm{As}$ ) was performed by ICP-MS using the same equipment described above. The organic contaminants were determined in the same sample by $\mathrm{GC}-$ MS after Soxhlet extraction (three- to six-ring PAHs, 18 PCB congeners and DDTs: $p p D D D, p p D D E$ and $p p D D T)$. Quantification was carried out similarly to the procedure described for the sediments, adapted to biological tissue (Martins et al. 2008).

\section{Metallothionein induction}

Metallothionein induction was determined by the quantification of thiols in whole soft tissue samples as described by Diniz et al. (2007) and Costa et al. (2008). In brief: samples were homogenized in Tris- $\mathrm{HCl} 0.02 \mathrm{M}$ buffer $(\mathrm{pH}$ 8.6). Homogenates were centrifuged at $30,000 \times g$ at $4^{\circ} \mathrm{C}$ for $1 \mathrm{~h}$. The supernatant was heated in a water bath at $80^{\circ} \mathrm{C}$ for $10 \mathrm{~min}$ to denature non-heat stable proteins and then centrifuged as previous. Thiols were quantified from heattreated cytosols by differential pulse polarography with a static mercury-drop electrode (DPP-SMDE) using a 693 VA processor and a 694 VA stand (Metrohm, Herisau, Switzerland). In absence of a commercial form of bivalve MT, Rabbit MT isoforms I \& II (Sigma, St Louis, MO, USA) was used for the standard addition method, as validated in bivalves by Diniz et al. (2007).

\section{Histopathology}

Cockles' digestive glands were fixed in Bouin-Holland's solution (27\% formaldehyde, $7 \%$ acetic acid, and picric acid until saturation) for approximately $48 \mathrm{~h}$ at room temperature. Afterwards, the samples were washed with water for $24 \mathrm{~h}$ to remove the excess picric acid, dehydrated in a progressive series of ethanol and intermediately embedded with xylene $(\approx 100 \%)$. Samples were then embedded in paraffin for about $12 \mathrm{~h}$. Sections ( $5 \mu \mathrm{m}$ thick) were stained with haematoxylin and eosin $(\mathrm{H} \& \mathrm{E})$ and 
mounted with DPX resin (BDH, Poole, UK). The procedure was adapted from Martoja and Martoja (1967). The slides were qualitatively analysed as a first attempt to identify exposure-induced lesions and alterations to the digestive gland of the species. A DMLB model bright-field microscope (from Leica Microsystems) was employed in the analyses.

Bioaccumulation and biota-to-soil accumulation factors

The bioaccumulation factor (BAF) and the biota-to-soil accumulation factor (BSAF) were measured regarding the trace elements $(\mathrm{Ni}, \mathrm{Cu}, \mathrm{Zn}, \mathrm{Cd}, \mathrm{Pb}$ and $\mathrm{As})$ and organic contaminants (PAHs, PCBs and DDTs). The BAF was calculated according to the formula (Lee 1992):

$\mathrm{BAF}=\frac{C_{\mathrm{o}}}{C_{\mathrm{s}}}$

where $C_{\mathrm{o}}$ was contaminant concentration in organism expressed in $\mathrm{mg} \mathrm{kg}^{-1}$ dry weight of tissue and $C_{\mathrm{s}}$ is the contaminant concentration in sediment expressed in $\mathrm{mg} \mathrm{kg}^{-1}$ dry weight of sediment. The BSAF is essentially the BAF normalized to the organic carbon content (TOM, given in \% relatively to sediment $\mathrm{dw}$ ) of the sediment (adapted from USEPA 1995):

$\mathrm{BSAF}=\frac{C_{\mathrm{o}}}{\left(\frac{C_{\mathrm{s}}}{\mathrm{TOM}}\right)}$

\section{Statistical analysis}

The non-parametric tests Kruskall-Wallis H and MannWhitney $\mathrm{U}$ were employed to assess global and pairwise statistical differences, respectively. The chi-square predicted $\times$ observed test was applied to assess significant differences between the concentrations of organic contaminants (for sediments and organisms). The non-parametric Spearman's rank order correlation $\rho$ statistic was used to assess the correlation between BAFs/BSAFs and metallothionein concentrations. A significance level of 5\% was set for all analyses. All the statistics were performed with Statistical Package for Social Sciences (SPSS Inc., Chicago, IL, USA).

\section{Results}

The assay's parameters (monitored weekly) were found to be constant throughout the assay: salinity $=34 \pm 1$, dissolved oxygen $=42 \pm 2 \%$, ammonia $\approx 0 \mathrm{mg} \mathrm{l}^{-1}, \mathrm{pH}=$ $7.8 \pm 0.1$, and temperature $=18 \pm 1^{\circ} \mathrm{C}$. Overall mortality was low for all tests $(3 \%, 4 \%$ and $11 \%$ for S1, S2 and S3 exposures, respectively).
Physico-chemical characterization of sediments

Fine fraction (FF) and TOM was lowest in the reference sediment (S1). Sediment fine fraction was highest in sediments S2 and in the culture sediment (CS), representing $98 \%$ and $94 \%$, respectively, of the total sediment dry weight. Sediments S2 and CS also had high organic matter content (11.8\% and $12.4 \%$, respectively). Sediments S2 and S3 were found the most reduced/anoxic sediments, presenting lowest Eh. CS is the only intertidal sediment and it is the less reduced. The results are summarized in Table 1. A linear relation was observed between FF and $\mathrm{TOM}$ content in sediments from the four sites $(\mathrm{FF}=6.4$, $\left.\mathrm{TOM}+20.7 ; r^{2}=0.96\right)$.

Contaminants in sediments

The results of the trace elements and organic concentrations in sediments from the four sites (the tested sediments plus the culture sediment) are presented in Table 2. The sediments S2 and the cockle mariculture sediment (CS) presented higher concentrations of trace elements, with values above TEL for all elements except $\mathrm{Cd}$, with the concentrations of $\mathrm{Zn}$ and $\mathrm{Cu}$ being found above PEL in sediment S2. Copper presented values above TEL in sediments $\mathrm{S} 1$ and $\mathrm{S} 3$ whereas As presented values above TEL in sediment $\mathrm{S} 3$ and slightly above TEL in sediment S1. The same pattern was found for $\mathrm{Zn}$ in sediment $\mathrm{S} 1$ and for $\mathrm{Pb}$ in sediment S3. The values of tPAHs obtained decreased in the following order: S3 $>$ S2 $>$ CS $\gg>S 1$. Four- and fivering PAHs were the best represented PAHs in all sediments.

Overall, the levels of the organic contaminants analysed were very low in the sediment S1 (the reference sediment) in comparison to other sediments. PAH levels above TEL were not found in the sediment S1, and only a few compounds of three-, four- and five-ring PAHs had concentrations above TEL in sediments S2, S3 and CS. Levels of tPCBs obtained decreased in the following order: S3 $\gg$ S2 $>$ CS $>$ S1, with no value above TEL. PCB-26

Table 1 Characterization of sediments from sites CS (cockle mariculture site), S1 (reference site) and contaminated sites S2 and S3

\begin{tabular}{llcl}
\hline Site & $\mathrm{FF}^{\mathrm{a}}(\%)$ & $\mathrm{TOM}(\%)$ & $\mathrm{Eh}^{\mathrm{b}}(\mathrm{mV})$ \\
\hline CS & 94 & 12.4 & -187 \\
S1 & 37 & 3.2 & -233 \\
S2 & 98 & 11.8 & -290 \\
S3 & 77 & 7.7 & -316 \\
\hline
\end{tabular}

FF fine fraction, TOM total organic matter

${ }^{\text {a }}$ Particle size $<63 \mu \mathrm{m}$

b Redox potential 
Table 2 Metal and organic contaminant concentrations of sediments from the cockle mariculture site (CS) and test sites, S1 (reference), S2 and S3 (contaminated). The sediment quality guidelines TEL and PEL were obtained from Macdonald et al. (1996)

\begin{tabular}{|c|c|c|c|c|c|c|c|c|c|c|}
\hline & \multirow[b]{3}{*}{ TEL } & \multirow[b]{3}{*}{ PEL } & \multicolumn{8}{|l|}{ Sites } \\
\hline & & & \multicolumn{2}{|l|}{$\mathrm{CS}$} & \multicolumn{2}{|l|}{$\mathrm{S} 1$} & \multicolumn{2}{|l|}{$\mathrm{S} 2$} & \multicolumn{2}{|l|}{ S3 } \\
\hline & & & & PEL-Q & & PEL-Q & & PEL-Q & & PEL-Q \\
\hline \multicolumn{11}{|c|}{ Metallic (mg kg ${ }^{-1}$ sediment dry weight) } \\
\hline As & 7.24 & 41.6 & $21 \pm 0.4^{\mathrm{a}}$ & 0.49 & $7.3 \pm 0.2^{\mathrm{a}}$ & 0.17 & $27 \pm 0.6^{\mathrm{a}}$ & 0.66 & $12 \pm 0.3^{\mathrm{a}}$ & 0.30 \\
\hline $\mathrm{Cd}$ & 0.68 & 4.21 & $0.2 \pm 0.005$ & 0.05 & $0.04 \pm 0.0008$ & 0.01 & $0.2 \pm 0.004$ & 0.05 & $0.2 \pm 0.003$ & 0.04 \\
\hline $\mathrm{Cu}$ & 18.7 & 108 & $64 \pm 1.3^{\mathrm{a}}$ & 0.59 & $23 \pm 0.5^{\mathrm{a}}$ & 0.21 & $167 \pm 3.4^{\mathrm{b}}$ & 1.55 & $41 \pm 0.8^{\mathrm{a}}$ & 0.38 \\
\hline $\mathrm{Ni}$ & 15.9 & 42.8 & $26 \pm 0.5^{\mathrm{a}}$ & 0.61 & $13 \pm 0.3$ & 0.30 & $34 \pm 0.7^{\mathrm{a}}$ & 0.79 & $9 \pm 0.2$ & 0.21 \\
\hline $\mathrm{Pb}$ & 30.2 & 112 & $31 \pm 0.6^{\mathrm{a}}$ & 0.28 & $24 \pm 0.5$ & 0.21 & $66 \pm 1.3^{\mathrm{a}}$ & 0.59 & $45 \pm 0.9^{\mathrm{a}}$ & 0.40 \\
\hline $\mathrm{Zn}$ & 124 & 271 & $233 \pm 4.7^{\mathrm{a}}$ & 0.86 & $147 \pm 3^{\mathrm{a}}$ & 0.54 & $312 \pm 6.2^{\mathrm{b}}$ & 1.15 & $88 \pm 1.8$ & 0.32 \\
\hline \multicolumn{11}{|c|}{ Organic contaminants ( $\mu \mathrm{g} \mathrm{kg}^{-1}$ sediment dry weight) } \\
\hline \multicolumn{11}{|c|}{ PAHs } \\
\hline \multicolumn{11}{|l|}{ Three-ring } \\
\hline Acenaphthene & 6.71 & 88.9 & $2.1 \pm 0.4$ & 0.02 & $1.4 \pm 0.2$ & 0.02 & $9.4 \pm 1.6^{\mathrm{a}}$ & 0.11 & $4.2 \pm 0.7$ & 0.05 \\
\hline Acenaphthylene & 5.87 & 128 & $4.6 \pm 0.8$ & 0.04 & $0.2 \pm 0.04$ & $\approx 0$ & $1.8 \pm 0.3$ & 0.01 & $2 \pm 0.3$ & 0.02 \\
\hline Anthracene & 46.9 & 245 & $5.7 \pm 1$ & 0.02 & $1 \pm 0.2$ & $\approx 0$ & $11 \pm 1$ & 0.04 & $15 \pm 2.6$ & 0.06 \\
\hline Fluorene & 21.2 & 144 & $3.6 \pm 0.6$ & 0.02 & $1.3 \pm 0.2$ & 0.01 & $8.7 \pm 1.5$ & 0.06 & $8 \pm 1.4$ & 0.06 \\
\hline Phenanthrene & 86.7 & 544 & $19 \pm 3.2$ & 0.03 & $8 \pm 1.4$ & 0.01 & $51 \pm 8.6$ & 0.09 & $54 \pm 9.2$ & 0.10 \\
\hline \multicolumn{11}{|l|}{ Four-ring } \\
\hline Benz(a)anthracene & 74.8 & 693 & $1 \pm 0.2$ & $\approx 0$ & $4.5 \pm 0.8$ & 0.01 & $65 \pm 11$ & 0.09 & $87 \pm 15^{\mathrm{a}}$ & 0.12 \\
\hline Chrysene & 108 & 846 & $3.5 \pm 0.6$ & $\approx 0$ & $2.2 \pm 0.4$ & $\approx 0$ & $28 \pm 4.8$ & 0.03 & $37 \pm 6.3$ & 0.04 \\
\hline Fluoranthene & 113 & 1494 & $186 \pm 31^{\mathrm{a}}$ & 0.12 & $18 \pm 3$ & 0.01 & $171 \pm 29^{\mathrm{a}}$ & 0.11 & $184 \pm 31^{\mathrm{a}}$ & 0.12 \\
\hline Pyrene & 153 & 1398 & $172 \pm 29^{\mathrm{a}}$ & 0.12 & $15 \pm 2.5$ & 0.01 & $132 \pm 22$ & 0.09 & $171 \pm 29^{a}$ & 0.12 \\
\hline \multicolumn{11}{|l|}{ Five-ring } \\
\hline Benzo(a)pyrene & 88.8 & 793 & $75 \pm 13$ & 0.09 & $7.6 \pm 1.3$ & 0.01 & $70 \pm 12$ & 0.09 & $86 \pm 15$ & 0.11 \\
\hline Benzo(b)fluoranthene & & & $57 \pm 9.6$ & & $6.8 \pm 1.2$ & & $61 \pm 10$ & & $70 \pm 12$ & \\
\hline Benzo(e)pyrene & & & $47 \pm 7.9$ & & $5.1 \pm 0.9$ & & $57 \pm 9.6$ & & $63 \pm 11$ & \\
\hline Benzo(k)fluoranthene & & & $25 \pm 4.3$ & & $4.2 \pm 0.7$ & & $32 \pm 5.5$ & & $40 \pm 6.8$ & \\
\hline Dibenzo(a,h)anthracene & 6.22 & 135 & $7.1 \pm 1.2^{\mathrm{a}}$ & 0.05 & $0.7 \pm 0.1$ & 0.01 & $7.5 \pm 1.3^{\mathrm{a}}$ & 0.06 & $7 \pm 1.2^{\mathrm{a}}$ & 0.05 \\
\hline Perylene & & & $40 \pm 6.8$ & & $4.7 \pm 0.8$ & & $87 \pm 15$ & & $209 \pm 36$ & \\
\hline \multicolumn{11}{|l|}{ Six-ring } \\
\hline Indene(1,2,3-cd)pyrene & & & $54 \pm 9.3$ & & $4.9 \pm 0.8$ & & $52 \pm 8.9$ & & $52 \pm 8.8$ & \\
\hline Benzo(g,h,I)perylene & & & $35 \pm 4.2$ & & $1.1 \pm 0.2$ & & $39 \pm 6.7$ & & $10 \pm 1.8$ & \\
\hline$\Sigma$ 3-ring & & & $35 \pm 5.9$ & & $12 \pm 2$ & & $81 \pm 14$ & & $84 \pm 14$ & \\
\hline$\Sigma 4$-ring & & & $362 \pm 62$ & & $39 \pm 6.7$ & & $395 \pm 67$ & & $479 \pm 82$ & \\
\hline$\Sigma 5$-ring & & & $250 \pm 43$ & & $29 \pm 4.9$ & & $314 \pm 53$ & & $475 \pm 81$ & \\
\hline$\Sigma 6$-ring & & & $89 \pm 15$ & & $6 \pm 1$ & & $92 \pm 16$ & & $62 \pm 11$ & \\
\hline tPAHs & & & $736 \pm 125$ & & $86 \pm 15$ & & $882 \pm 150$ & & $1100 \pm 187$ & \\
\hline \multicolumn{11}{|l|}{ PCBs } \\
\hline \multicolumn{11}{|l|}{ Trichlorinated } \\
\hline PCB-18 & & & $0.2 \pm 0.04$ & & $<$ d.l. & & $0.08 \pm 0.01$ & & $0.09 \pm 0.02$ & \\
\hline PCB-26 & & & $1.8 \pm 0.3$ & & $<$ d.l. & & $0.06 \pm 0.01$ & & $0.09 \pm 0.02$ & \\
\hline PCB-31 & & & $0.1 \pm 0.02$ & & $0.6 \pm 0.1$ & & $0.2 \pm 0.03$ & & $<$ d.l. & \\
\hline \multicolumn{11}{|l|}{ Tetra-chlorinated } \\
\hline PCB-44 & & & $0.05 \pm 0.01$ & & $<$ d.l. & & $0.4 \pm 0.06$ & & $<\mathrm{d} .1$ & \\
\hline PCB-49 & & & $0.05 \pm 0.01$ & & $<$ d.l. & & $0.08 \pm 0.01$ & & $0.4 \pm 0.06$ & \\
\hline PCB-52 & & & $0.08 \pm 0.01$ & & $<$ d.l. & & $0.1 \pm 0.02$ & & $0.5 \pm 0.08$ & \\
\hline
\end{tabular}


Table 2 continued

\begin{tabular}{|c|c|c|c|c|c|c|c|c|c|c|}
\hline & \multirow[b]{3}{*}{ TEL } & \multirow[b]{3}{*}{ PEL } & \multicolumn{8}{|l|}{ Sites } \\
\hline & & & \multicolumn{2}{|l|}{$\mathrm{CS}$} & \multicolumn{2}{|l|}{ S1 } & \multicolumn{2}{|l|}{ S2 } & \multicolumn{2}{|l|}{$\mathrm{S} 3$} \\
\hline & & & & PEL-Q & & PEL-Q & & PEL-Q & & PEL-Q \\
\hline \multicolumn{11}{|l|}{ Penta-chlorinated } \\
\hline PCB-101 & & & $0.06 \pm 0.01$ & & $<$ d.l. & & $0.2 \pm 0.04$ & & $1.2 \pm 0.2$ & \\
\hline PCB-105 & & & $<$ d.l. & & $<$ d.l. & & $0.2 \pm 0.04$ & & $0.7 \pm 0.1$ & \\
\hline PCB-118 & & & $0.08 \pm 0.01$ & & $<$ d.l. & & $1 \pm 0.2$ & & $4.9 \pm 0.8$ & \\
\hline \multicolumn{11}{|l|}{ Hexa-chlorinated } \\
\hline PCB-128 & & & $0.05 \pm 0.01$ & & $<$ d.l. & & $0.08 \pm 0.01$ & & $<$ d.1. & \\
\hline PCB-138 & & & $0.2 \pm 0.04$ & & $0.1 \pm 0.02$ & & $0.7 \pm 0.1$ & & $2.7 \pm 0.5$ & \\
\hline PCB-149 & & & $0.1 \pm 0.02$ & & $0.1 \pm 0.02$ & & $<\mathrm{d} .1$ & & $<$ d.l. & \\
\hline PCB-151 & & & $0.09 \pm 0.02$ & & $0.05 \pm 0.01$ & & $0.2 \pm 0.03$ & & $1.2 \pm 0.2$ & \\
\hline PCB-153 & & & $0.2 \pm 0.03$ & & $0.1 \pm 0.02$ & & $0.6 \pm 0.1$ & & $3.4 \pm 0.6$ & \\
\hline \multicolumn{11}{|l|}{ Hepta-chlorinated } \\
\hline PCB-170 & & & $0.03 \pm 0.005$ & & $0.07 \pm 0.01$ & & $0.3 \pm 0.05$ & & $<$ d.1. & \\
\hline PCB-180 & & & $0.1 \pm 0.02$ & & $0.2 \pm 0.04$ & & $0.6 \pm 0.1$ & & $<$ d.1. & \\
\hline PCB-187 & & & $0.2 \pm 0.04$ & & $0.2 \pm 0.03$ & & $0.7 \pm 0.1$ & & $<$ d.l. & \\
\hline PCB-194 & & & $0.03 \pm 0.005$ & & $<$ d.l. & & $0.07 \pm 0.01$ & & $0.4 \pm 0.06$ & \\
\hline$\Sigma$ Tri-chlorinated & & & $2.1 \pm 0.4$ & & $0.6 \pm 0.1$ & & $0.3 \pm 0.06$ & & $0.2 \pm 0.03$ & \\
\hline$\Sigma$ Tetra-chlorinated & & & $0.2 \pm 0.03$ & & $<$ d.l. & & $0.6 \pm 0.1$ & & $0.8 \pm 0.1$ & \\
\hline$\Sigma$ Penta-chlorinated & & & $0.1 \pm 0.02$ & & $<$ d.l. & & $1.5 \pm 0.3$ & & $6.8 \pm 1.2$ & \\
\hline$\Sigma$ Hexa-chlorinated & & & $0.7 \pm 0.1$ & & $0.4 \pm 0.07$ & & $1.6 \pm 0.3$ & & $7.2 \pm 1.2$ & \\
\hline$\Sigma$ Hepta-chlorinated & & & $0.4 \pm 0.07$ & & $0.5 \pm 0.08$ & & $1.7 \pm 0.3$ & & $0.4 \pm 0.06$ & \\
\hline tPCBs & 21.6 & 189 & $3.5 \pm 0.6$ & 0.02 & $1.5 \pm 0.3$ & 0.01 & $5.6 \pm 1$ & 0.03 & $15 \pm 2.6$ & 0.08 \\
\hline \multicolumn{11}{|l|}{ DDTs } \\
\hline$p p \mathrm{DDD}$ & 1.22 & 7.81 & $<$ d.1. & $<$ d.1. & $0.1 \pm 0.02$ & 0.01 & $0.3 \pm 0.05$ & 0.04 & $0.6 \pm 0.1$ & 0.08 \\
\hline$p p \mathrm{DDE}$ & 2.07 & 374 & $0.09 \pm 0.02$ & $\approx 0$ & $0.05 \pm 0.01$ & $\approx 0$ & $0.3 \pm 0.05$ & $\approx 0$ & $0.7 \pm 0.1$ & $\approx 0$ \\
\hline$p p \mathrm{DDT}$ & 1.19 & 4.77 & $<$ d.l. & $<$ d.l. & $0.7 \pm 0.1$ & 0.15 & $4.4 \pm 0.8^{\mathrm{a}}$ & 0.92 & $1.2 \pm 0.2$ & 0.25 \\
\hline tDDTs & & & $0.09 \pm 0.02$ & & $0.9 \pm 0.1$ & & $4.9 \pm 0.8$ & & $2.4 \pm 0.4$ & \\
\hline SQG-Q & & & & 0.181 & & 0.082 & & 0.313 & & 0.139 \\
\hline SQG-Q metallic & & & & 0.481 & & 0.242 & & 0.799 & & 0.275 \\
\hline SQG-Q organic & & & & 0.043 & & 0.017 & & 0.119 & & 0.084 \\
\hline
\end{tabular}

$T E L$ threshold effects level, $P E L$ probable effects level, $P E L-Q$ PEL quotient [1], $S Q G-Q$ sediment quality guideline quotient [2], $P A H$ polycyclic aromatic hydrocarbons, $<d$.l. below detection limit, $t P A H$ total PAHs, $P C B$ polychlorinated biphenyls, $t P C B$ total PCBs, $D D D$ 1,1dichloro-2,2-bis( $\rho$-chlorophenyl)ethane, $D D E$ 1,1-dichloro-2,2-bis ( $\rho$-chlorophenyl)ethylene, $D D T$ 1,1,1-trichloro2,2-bis ( $\rho$-chlorophenyl)ethane, $t D D T$ total DDTs. Ranges indicate standard error

${ }^{a}$ Concentrations above TEL

${ }^{\mathrm{b}}$ Concentrations above PEL

(tri-chlorinated) was the congener with the highest concentration in sediment CS; penta-, hexa- and hepta-chlorinated reached the highest concentration in sediment $\mathrm{S} 2$; penta- and hexa-chlorinated in sediment S3. Congeners with the highest concentration in sediment S3 were PCB101 and PCB-118 (penta-chlorinated) and PCB-138, PCB151 and PCB-153 (hexa-chlorinated). The values of tDDTs obtained decreased in the following order: $\mathrm{S} 2>\mathrm{S} 3>$ S1 > CS. Sediment CS presents very low concentrations of tDDTs, $p p D D E$ was the only compound above detection limit. $p p \mathrm{DDT}$ was the form with the highest concentrations in sediments S1, S2 and S3, particularly in sediment S2, being the most important DDT. The SQG-Qs obtained for the four sediments follow the sequence (from worst to best sediment quality): S2 $>\mathrm{CS}>\mathrm{S} 3>\mathrm{S} 1$, placing the mariculture sediment in an intermediate level of contamination. Due to the high metallic weight in total SQG-Q for all sediments, this quotient follows the same sequence as metal SQG-Q. In comparison, organic contaminant SQGGs show the following sequence: $\mathrm{S} 2>\mathrm{S} 3>\mathrm{CS}>\mathrm{S} 1$. 
Bioaccumulation and metallothioneins in C. edule

The results from metallothionein concentration and bioaccumulation in whole soft tissue are presented in Table 3. A very significant decrease of metallothioneins over time stands out in organisms exposed to sediments from site S3.
Exposure to the contaminated sediments caused a significant decrease in the MT content comparatively to bivalves exposed to the reference sediment (S1) at T14 and, at T28 only for exposure to S3 (Mann-Whitney $\mathrm{U}, p<0.05$ ). Exposure to $\mathrm{S} 3$ revealed lower MT concentrations than for $\mathrm{S} 2$ at T28 (Mann-Whitney $\mathrm{U}, p<0.05)$.

Table 3 Metallothionein and bioaccumulation of metal and organic contaminants in Cerastoderma edule exposed to sediments collected from sites S1 (reference), S2 and S3 (contaminated). The sediment CS was collected from the cockles' culture site

\begin{tabular}{|c|c|c|c|c|c|c|c|}
\hline & \multicolumn{7}{|l|}{ Site } \\
\hline & \multirow{2}{*}{$\begin{array}{l}\text { CS } \\
\text { (T0) }\end{array}$} & \multicolumn{2}{|l|}{ S1 } & \multicolumn{2}{|l|}{$\mathrm{S} 2$} & \multicolumn{2}{|l|}{ S3 } \\
\hline & & T14 & $\mathrm{T} 28$ & $\mathrm{~T} 14$ & $\mathrm{~T} 28$ & T14 & T28 \\
\hline $\begin{array}{l}\text { Metallothioneins ( } \mathrm{mg} \mathrm{g}^{-1} \text { whole } \\
\text { soft tissue dry weight) } \\
\pm \text { standard deviation }\end{array}$ & $3.5 \pm 1.7$ & $3.8 \pm 1.2$ & $2.4 \pm 0.7$ & $2.7 \pm 0.6^{\dagger}$ & $2.7 \pm 1.4$ & $2.1 \pm 0.8^{*}, \dagger$ & $1.7 \pm 0.7^{*}, \dagger$ \\
\hline \multicolumn{8}{|c|}{ Metals ( $\mathrm{mg} \mathrm{kg}^{-1}$ whole soft tissue dry weight) \pm standard deviation } \\
\hline As & $17 \pm 3.3$ & $17 \pm 2.5$ & $22 \pm 4.3^{*}$ & $24 \pm 7.4^{*}, \dagger$ & $23 \pm 2.7^{* *}$ & $23 \pm 6.6^{* *}, \dagger$ & $22 \pm 6.8^{*}$ \\
\hline $\mathrm{Cd}$ & $1.3 \pm 1.6$ & $2 \pm 1.6$ & $1.6 \pm 1.3$ & $1.4 \pm 1.2$ & $2.2 \pm 2$ & $2.8 \pm 2.9$ & $1 \pm 1$ \\
\hline $\mathrm{Cu}$ & $21 \pm 8.6$ & $15 \pm 9.4^{*}$ & $12 \pm 3.8^{* *}$ & $14 \pm 3.3^{*}$ & $34 \pm 15^{*}, \dagger$ & $16 \pm 6$ & $22 \pm 13^{\dagger}$ \\
\hline $\mathrm{Ni}$ & $91 \pm 32$ & $84 \pm 17$ & $96 \pm 16$ & $107 \pm 45$ & $107 \pm 40$ & $117 \pm 37^{*},^{\dagger}$ & $84 \pm 61$ \\
\hline $\mathrm{Pb}$ & $5.3 \pm 2.9$ & $6.1 \pm 6.3$ & $3 \pm 1.2 *$ & $8.2 \pm 8.2$ & $6.2 \pm 4.3^{\dagger}$ & $6.3 \pm 3.2$ & $4.5 \pm 2.8$ \\
\hline $\mathrm{Zn}$ & $85 \pm 29$ & $68 \pm 10$ & $97 \pm 21$ & $112 \pm 41^{\dagger \dagger}$ & $130 \pm 44^{* *, \dagger}$ & $160 \pm 76^{* *}, \dagger$ & $113 \pm 57$ \\
\hline \multicolumn{8}{|c|}{ Organic contaminants ( $\mu \mathrm{g} \mathrm{kg}^{-1}$ whole soft tissue dry weight) \pm standard error } \\
\hline \multicolumn{8}{|c|}{ PAHs } \\
\hline \multicolumn{8}{|l|}{ Three-ring } \\
\hline Acenaphthene & $0.7 \pm 0.1$ & $0.8 \pm 0.1$ & $0.7 \pm 0.1$ & $1.5 \pm 0.3$ & $1.5 \pm 0.3$ & $2.3 \pm 0.4$ & $1.6 \pm 0.3$ \\
\hline Acenaphthylene & $0.3 \pm 0.06$ & $0.4 \pm 0.06$ & $0.4 \pm 0.06$ & $0.7 \pm 0.1$ & $0.7 \pm 0.1$ & $0.8 \pm 0.1$ & $0.7 \pm 0.1$ \\
\hline Anthracene & $1.1 \pm 0.2$ & $1.1 \pm 0.2$ & $1.1 \pm 0.2$ & $0.3 \pm 0.06$ & $0.4 \pm 0.06$ & $0.4 \pm 0.07$ & $0.3 \pm 0.06$ \\
\hline Fluorene & $2.6 \pm 0.5$ & $2.6 \pm 0.4$ & $2.7 \pm 0.5$ & $1.3 \pm 0.2$ & $1.7 \pm 0.3$ & $1.8 \pm 0.3$ & $1.6 \pm 0.3$ \\
\hline Phenanthrene & $5.1 \pm 0.9$ & $6.8 \pm 1.2$ & $6.7 \pm 1.1$ & $4.1 \pm 0.7$ & $4.9 \pm 0.8$ & $5.9 \pm 1$ & $4.7 \pm 0.8$ \\
\hline \multicolumn{8}{|l|}{ Four-ring } \\
\hline Benz(a)anthracene & $0.2 \pm 0.03$ & $0.3 \pm 0.06$ & $0.3 \pm 0.05$ & $0.6 \pm 0.1$ & $0.7 \pm 0.1$ & $1.2 \pm 0.2$ & $1.4 \pm 0.2$ \\
\hline Chrysene & $0.9 \pm 0.2$ & $0.7 \pm 0.1$ & $0.7 \pm 0.1$ & $0.9 \pm 0.2$ & $1.9 \pm 0.3$ & $1.9 \pm 0.3$ & $1.1 \pm 0.2$ \\
\hline Fluoranthene & $5.8 \pm 1$ & $5.8 \pm 1$ & $5.9 \pm 1$ & $4.5 \pm 0.8$ & $4.6 \pm 0.8$ & $6.2 \pm 1$ & $5 \pm 0.9$ \\
\hline Pyrene & $8.4 \pm 1.4$ & $7 \pm 1.2$ & $7 \pm 1.2$ & $4.6 \pm 0.8$ & $5.2 \pm 0.9$ & $8 \pm 1.4$ & $6.8 \pm 1.2$ \\
\hline \multicolumn{8}{|l|}{ Five-ring } \\
\hline Benzo(a)pyrene & $3 \pm 0.5$ & $2.7 \pm 0.5$ & $2.8 \pm 0.5$ & $0.6 \pm 0.1$ & $0.6 \pm 0.1$ & $1.2 \pm 0.2$ & $1.3 \pm 0.2$ \\
\hline Benzo(b)fluoranthene & $1.2 \pm 0.2$ & $1.3 \pm 0.2$ & $1.2 \pm 0.2$ & $1 \pm 0.2$ & $1.2 \pm 0.2$ & $1.4 \pm 0.3$ & $1.5 \pm 0.3$ \\
\hline Benzo(e)pyrene & $0.5 \pm 0.09$ & $0.6 \pm 0.1$ & $0.6 \pm 0.09$ & $0.7 \pm 0.1$ & $0.7 \pm 0.1$ & $1.2 \pm 0.2$ & $1.2 \pm 0.2$ \\
\hline Benzo(k)fluoranthene & $0.2 \pm 0.03$ & $0.2 \pm 0.04$ & $0.2 \pm 0.04$ & $0.6 \pm 0.1$ & $0.6 \pm 0.1$ & $0.7 \pm 0.1$ & $0.9 \pm 0.1$ \\
\hline Dibenzo(a,h)anthracene & $<$ d.l. & $<$ d.l. & $<$ d.l. & $<$ d.l. & $<$ d.l. & $<$ d.l. & $<$ d.l. \\
\hline Perylene & $1 \pm 0.2$ & $0.7 \pm 0.1$ & $0.4 \pm 0.07$ & $1.7 \pm 0.3$ & $1.7 \pm 0.3$ & $6 \pm 1$ & $6.9 \pm 1.2$ \\
\hline \multicolumn{8}{|l|}{ Six-ring } \\
\hline Indene(1,2,3-cd)pyrene & $<$ d.l. & $<$ d.l. & $4.4 \pm 0.7$ & $0.6 \pm 0.1$ & $0.6 \pm 0.1$ & $0.7 \pm 0.1$ & $0.7 \pm 0.1$ \\
\hline Benzo(g,h,I)perylene & $<$ d.l. & $<$ d.l. & $3.7 \pm 0.6$ & $0.5 \pm 0.09$ & $0.8 \pm 0.1$ & $0.8 \pm 0.1$ & $0.8 \pm 0.1$ \\
\hline$\Sigma 3$-ring & $9.9 \pm 1.7$ & $12 \pm 2$ & $12 \pm 2$ & $7.9 \pm 1.3$ & $9.1 \pm 1.6$ & $11 \pm 1.9$ & $8.9 \pm 1.5$ \\
\hline ¿4-ring & $15 \pm 2.6$ & $14 \pm 2.3$ & $14 \pm 2.4$ & $11 \pm 1.8$ & $12 \pm 2.1$ & $17 \pm 2.9$ & $14 \pm 2.4$ \\
\hline$\Sigma 5$-ring & $5.8 \pm 1$ & $5.6 \pm 0.9$ & $5.2 \pm 0.9$ & $4.6 \pm 0.8$ & $4.8 \pm 0.8$ & $11 \pm 1.8$ & $12 \pm 2$ \\
\hline इ6-ring & $<$ d.1. & $<$ d.l. & $8 \pm 1.4$ & $1.2 \pm 0.2$ & $1.3 \pm 0.2$ & $1.6 \pm 0.3$ & $1.5 \pm 0.2$ \\
\hline tPAHs & $31 \pm 5.3$ & $31 \pm 5.3$ & $39 \pm 6.6$ & $24 \pm 4.1$ & $28 \pm 4.7$ & $41 \pm 6.9^{* *}, \dagger$ & $36 \pm 6.2 * *, \dagger$ \\
\hline
\end{tabular}


Table 3 continued

\begin{tabular}{|c|c|c|c|c|c|c|c|}
\hline & \multicolumn{7}{|l|}{ Site } \\
\hline & \multirow{2}{*}{$\begin{array}{l}\text { CS } \\
\text { (T0) }\end{array}$} & \multicolumn{2}{|l|}{$\mathrm{S} 1$} & \multicolumn{2}{|l|}{ S2 } & \multicolumn{2}{|l|}{ S3 } \\
\hline & & $\mathrm{T} 14$ & $\mathrm{~T} 28$ & $\mathrm{~T} 14$ & $\mathrm{~T} 28$ & $\mathrm{~T} 14$ & $\mathrm{~T} 28$ \\
\hline \multicolumn{8}{|l|}{ PCBs } \\
\hline \multicolumn{8}{|l|}{ Trichlorinated } \\
\hline PCB-18 & $0.02 \pm 0.003$ & $<$ d.l. & $0.03 \pm 0.005$ & $0.03 \pm 0.005$ & $0.06 \pm 0.01$ & $0.01 \pm 0.002$ & $0.02 \pm 0.003$ \\
\hline PCB-26 & $0.02 \pm 0.003$ & $<$ d.l. & $<$ d.l. & $0.01 \pm 0.002$ & $0.02 \pm 0.003$ & $<$ d.l. & $0.01 \pm 0.002$ \\
\hline PCB-31 & $<$ d.l. & $<$ d.l. & $0.2 \pm 0.03$ & $0.4 \pm 0.07$ & $0.5 \pm 0.08$ & $<$ d.l. & $0.5 \pm 0.09$ \\
\hline \multicolumn{8}{|l|}{ Tetra-chlorinated } \\
\hline PCB-44 & $0.04 \pm 0.01$ & $0.06 \pm 0.01$ & $0.04 \pm 0.01$ & $0.07 \pm 0.01$ & $0.09 \pm 0.01$ & $0.02 \pm 0.003$ & $0.03 \pm 0.01$ \\
\hline PCB-49 & $0.06 \pm 0.01$ & $0.1 \pm 0.02$ & $0.1 \pm 0.02$ & $0.06 \pm 0.01$ & $0.08 \pm 0.01$ & $0.02 \pm 0.003$ & $0.03 \pm 0.01$ \\
\hline PCB-52 & $0.03 \pm 0.01$ & $0.08 \pm 0.01$ & $0.03 \pm 0.01$ & $0.06 \pm 0.01$ & $0.08 \pm 0.01$ & $0.02 \pm 0.003$ & $0.01 \pm 0.002$ \\
\hline \multicolumn{8}{|l|}{ Penta-chlorinated } \\
\hline PCB-101 & $0.03 \pm 0.01$ & $0.09 \pm 0.01$ & $0.02 \pm 0.003$ & $0.05 \pm 0.01$ & $0.07 \pm 0.01$ & $0.05 \pm 0.01$ & $0.03 \pm 0.01$ \\
\hline PCB-105 & $0.03 \pm 0.01$ & $<$ d.l. & $<$ d.1. & $<$ d.l. & $<$ d.l. & $<$ d.l. & $<$ d.1. \\
\hline PCB-118 & $0.2 \pm 0.03$ & $0.3 \pm 0.05$ & $0.2 \pm 0.04$ & $0.2 \pm 0.03$ & $0.2 \pm 0.03$ & $0.1 \pm 0.02$ & $0.1 \pm 0.02$ \\
\hline \multicolumn{8}{|l|}{ Hexa-chlorinated } \\
\hline PCB-128 & $<$ d.l. & $<$ d.l. & $<$ d.l. & $0.01 \pm 0.002$ & $<$ d.l. & $<$ d.1. & $<$ d.l. \\
\hline PCB-138 & $0.08 \pm 0.01$ & $0.1 \pm 0.02$ & $0.09 \pm 0.01$ & $0.1 \pm 0.02$ & $0.05 \pm 0.01$ & $0.05 \pm 0.01$ & $0.08 \pm 0.01$ \\
\hline PCB-149 & $<$ d.1. & $<$ d.l. & $<$ d.l. & $<$ d.l. & $<$ d.l. & $<$ d.1. & $<$ d.1. \\
\hline PCB-151 & $<$ d.l. & $<$ d.l. & $<$ d.1. & $<$ d.1. & $<\mathrm{d} .1$ & $<$ d.1. & $<$ d.1. \\
\hline PCB-153 & $0.03 \pm 0.01$ & $0.06 \pm 0.01$ & $<\mathrm{d} .1$ & $0.02 \pm 0.003$ & $<$ d.l. & $<$ d.l. & $0.02 \pm 0.003$ \\
\hline \multicolumn{8}{|l|}{ Hepta-chlorinated } \\
\hline PCB-170 & $<$ d.l. & $<\mathrm{d} .1$ & $<$ d.1. & $<$ d.1. & $<$ d.l. & $<$ d.1. & $<\mathrm{d} .1$ \\
\hline PCB-180 & $<$ d.1. & $<$ d.l. & $<$ d.1. & $<$ d.1. & $<$ d.l. & $<$ d.l. & $<$ d.l. \\
\hline PCB-187 & $<$ d.l. & $<$ d.l. & $<$ d.l. & $<$ d.l. & $<$ d.l. & $<$ d.l. & $<$ d.l. \\
\hline PCB-194 & $<$ d.l. & $<$ d.l. & $<$ d.l. & $<$ d.l. & $<$ d.l. & $<$ d.l. & $<$ d.l. \\
\hline$\Sigma$ Tri-chlorinated & $0.05 \pm 0.01$ & $<$ d.l. & $0.2 \pm 0.04$ & $0.5 \pm 0.08$ & $0.5 \pm 0.09$ & $0.01 \pm 0.002$ & $0.6 \pm 0.09$ \\
\hline$\Sigma$ Tetra-chlorinated & $0.1 \pm 0.02$ & $0.2 \pm 0.04$ & $0.2 \pm 0.03$ & $0.2 \pm 0.03$ & $0.2 \pm 0.04$ & $0.06 \pm 0.01$ & $0.08 \pm 0.01$ \\
\hline$\Sigma$ Penta-chlorinated & $0.2 \pm 0.04$ & $0.4 \pm 0.07$ & $0.3 \pm 0.04$ & $0.3 \pm 0.04$ & $0.3 \pm 0.04$ & $0.2 \pm 0.03$ & $0.2 \pm 0.03$ \\
\hline$\Sigma$ Hexa-chlorinated & $0.1 \pm 0.02$ & $0.2 \pm 0.03$ & $0.09 \pm 0.01$ & $0.2 \pm 0.02$ & $0.05 \pm 0.01$ & $0.05 \pm 0.01$ & $0.09 \pm 0.02$ \\
\hline$\Sigma$ Hepta-chlorinated & $<$ d.l. & $<$ d.l. & $<$ d.l. & $<$ d.l. & $<$ d.l. & $<$ d.l. & $<$ d.l. \\
\hline tPCBs & $0.5 \pm 0.08$ & $0.8 \pm 0.1$ & $0.7 \pm 0.13$ & $1 \pm 0.2$ & $1.1 \pm 0.2$ & $0.3 \pm 0.05$ & $0.9 \pm 0.2$ \\
\hline \multicolumn{8}{|l|}{ DDTs } \\
\hline$p p \mathrm{DDD}$ & $2.2 \pm 0.4$ & $0.5 \pm 0.09$ & $0.6 \pm 0.1$ & $0.2 \pm 0.04$ & $1.3 \pm 0.2$ & $0.2 \pm 0.04$ & $0.3 \pm 0.05$ \\
\hline$p p \mathrm{DDE}$ & $0.1 \pm 0.02$ & $0.2 \pm 0.04$ & $0.1 \pm 0.02$ & $0.1 \pm 0.02$ & $0.2 \pm 0.03$ & $0.08 \pm 0.01$ & $0.1 \pm 0.02$ \\
\hline$p p D D T$ & $1.1 \pm 0.2$ & $1 \pm 0.2$ & $1.4 \pm 0.2$ & $1.1 \pm 0.2$ & $4.1 \pm 0.7$ & $0.5 \pm 0.09$ & $0.6 \pm 0.1$ \\
\hline tDDTs & $3.5 \pm 0.6$ & $1.8 \pm 0.3$ & $2.1 \pm 0.4$ & $1.4 \pm 0.2$ & $5.6 \pm 1 *$ & $0.8 \pm 0.1$ & $1 \pm 0.2$ \\
\hline
\end{tabular}

$P A H$ polycyclic aromatic hydrocarbons, $t P A H$ total PAHs, $P C B$ polychlorinated biphenyls, $t P C B$ total PCBs, $D D D$ 1,1-dichloro-2,2-bis $(\rho-$ chlorophenyl)ethane, $D D E$ 1,1-dichloro-2,2-bis ( $\rho$-chlorophenyl)ethylene, $D D T$ 1,1,1-trichloro2,2-bis ( $\rho$-chlorophenyl)ethane, $t D D T$ total DDTs, $<$ d.l. below detection limit, $*$ and $* *$ indicate significant differences $(p<0.05$ and $p<0.01$, respectively) between tests and CS (Mann-Whitney $\mathrm{U}$ test for metals and chi-square test for organic contaminants); ${ }^{\dagger}$ and ${ }^{\dagger \dagger}$ indicate significant differences $(p<0.05$ and $p<0.01$, respectively) between tests and S1 (Mann-Whitney U test for metals and chi-square test for organic contaminants)

The highest metal bioaccumulation was observed in organisms exposed to sediments S2, with a significant increase compared to the animals from CS (T0) being reported for $\mathrm{As}$ and $\mathrm{Cu}$ (at both $\mathrm{T} 14$ and T28) and $\mathrm{Zn}$ (at T28) and also with a significant increase compared to the animals exposed to the reference sediment $\mathrm{Zn}$ (at T14 and
$\mathrm{T} 28$ ); for $\mathrm{Cu}$ and $\mathrm{Pb}$ (at $\mathrm{T} 28$ ) and $\mathrm{As}$ at $\mathrm{T} 14$ (MannWhitney $\mathrm{U}, p<0.05)$. Regarding S2-exposed bivalves, Ni concentrations in whole-body where only significantly higher at T28 and comparing to the animals exposed to $\mathrm{S} 3$ (Mann-Whitney $\mathrm{U}, p<0.05$ ). On the other hand, exposure to S3, comparing to animals from CS, depicted a 
significantly higher accumulation of As at both T14 and T28 and of Ni and $\mathrm{Zn}$ at T14 and, comparing to animals exposed to the reference sediment, a significantly higher accumulation of $\mathrm{As}, \mathrm{Ni}, \mathrm{Zn}$ at $\mathrm{T} 14$ and $\mathrm{Cu}$ at $\mathrm{T} 28$ was observed (Mann-Whitney $\mathrm{U}, p<0.05$ ). Nevertheless, an overall lower metal bioaccumulation was observed in organisms exposed to S3 than S2. Cadmium bioaccumulation was, in general, very low and no significant differences between tests and sampling times were found.

Three- and four-ring compounds (in all cockles) and five-ring compounds (only in cockles exposed to sediment S3) were the best represented PAHs. Still, only animals exposed to sediment $\mathrm{S} 3$ revealed significantly higher $\mathrm{PAH}$ bioaccumulation relatively to T0 cockles and cockles exposed to the reference sediment for 14 days (MannWhitney $\mathrm{U}, p<0.01)$. However, at T28, S3-exposed animals revealed lesser tPAHs concentrations than bivalves exposed to the reference sediment (Mann-Whitney $\mathrm{U}$, $p<0.01)$. Tri-chlorinated were the most representative PCBs accumulated in cockles exposed to sediment S2 and in the sediment S3 after 28 days of exposure. Higher molecular weight PCBs, especially penta-chlorinated, accumulated more noticeably in animals exposed to sediment S3 for 14 days. However, no significant differences were observed between total PCB bioaccumulation between tests and sampling times. Only cockles exposed to sediment S2 (the most contaminated by DDTs) for 28 days were found to have significantly accumulated tDDTs (especially $p p D D T$ ) relatively to cockles exposed to the reference sediments and also to T0 bivalves (MannWhitney $\mathrm{U}, p<0.05)$.

\section{BAFs and BSAFs}

The BAFs and BSAFs are presented in the Table 4. For many PCBs, BAF value in S1 cockles is not available data because the concentration is below detection limit, so regardless these, regarding exposure to sediment S1, BAFs for all contaminants (except benz(a)anthracene and DDTs) were higher than in unexposed animals, from the culture sediment CS (T0 animals). In sediment S3, BAFs for all metals (except $\mathrm{Pb}$ ) were higher than in the sediment $\mathrm{CS}$ and BAFs for PCBs were extremely lower than in the other sediments. BSAFs for organic contaminants were generally lower in sediments S1, S2 and S3 than in CS, except BSAF for PAHs in sediment S1 and BSAF for PCBs in sediment $\mathrm{S} 2$. In general, BSAFs were lower also for metals, except $\mathrm{Cd}$ in sediment $\mathrm{S} 1$ and $\mathrm{S} 2$, and $\mathrm{As}, \mathrm{Cd}, \mathrm{Ni}$ and $\mathrm{Zn}$ in sediment S3. Combining the bioaccumulation factors for cockles retrieved at $\mathrm{T} 14$ and $\mathrm{T} 28$ revealed that both $\mathrm{BAF}$ and BSAF for $\mathrm{Cd}$ and BSAF for PAHs were highly correlated to MT induction (Spearman's $\rho, p<0.05$ ).
Histopathology

The digestive gland of T0 individuals (cultured cockles) showed an essentially normal morphology (Fig. 2A, B). In comparison, the digestive gland of cockles exposed to all sediments showed alterations from T0 animals, including bivalves exposed to the reference sediment (S1), even though the alterations in this case were pronounced only at T28. Deterioration of the digestive gland tubules was observed in organisms from sediments S1, S2 and S3 but with the animals exposed to sediments S2 and S3 (the most contaminated) enduring the most severe lesions. The histological alterations were present in most organisms and varied depending on sediment and time of exposure. A decrease of connective tissue was observed in damaged digestive glands (Fig. 2D-H). The number of excretory cells slightly increased in sediment S1 (Fig. 2C) and very considerably in sediment S3 (Fig. 2G). The tubule cells became detached from the basal layer in cockles exposed to sediment S2, the most contaminated (Fig. 2E, F), and at T28 in cockles exposed to the reference sediment (Fig. 2D), and S3 (Fig. 2H). Hyperplasia of epithelial cells was found in the digestive gland of animals exposed to sediment S2 (Fig. 2E).

\section{Discussion}

The present study demonstrated that $C$. edule depicted effects and responses to the exposure to estuarine sediments, while enduring 28-day laboratory assays during which low mortality occurred. However, while the exposure to contaminated sediments elicited more severe histopathological alteration when compared to the exposure to the reference sediment, the bioaccumulation and MT induction analyses revealed unexpected variations that may not directly reflect the levels of xenobiotics in the tested sediments. These variations may be especially explained by (i) differences in the sediment characteristics that affect bioavailability (ii) the initial condition of the cockles, since the culture sediment from which they were collected was found to be moderately contaminated and (iii) the interaction effects between the several classes of contaminants.

In our study, BAF values generally presented a similar evolution, decreasing when sediment TOM increased, which is in accordance with previous works (e.g. Jantunen et al. 2008). An exception, however, was observed regarding organic contaminants: BAF of PCBs in the sediment S3 was much lower than in other sediments, which may be due to the existence of a higher concentration of PCBs in this sediment and to a possible constancy of PCB assimilation, regardless of the initial concentration in the environment. The opposite was observed for PAHs 


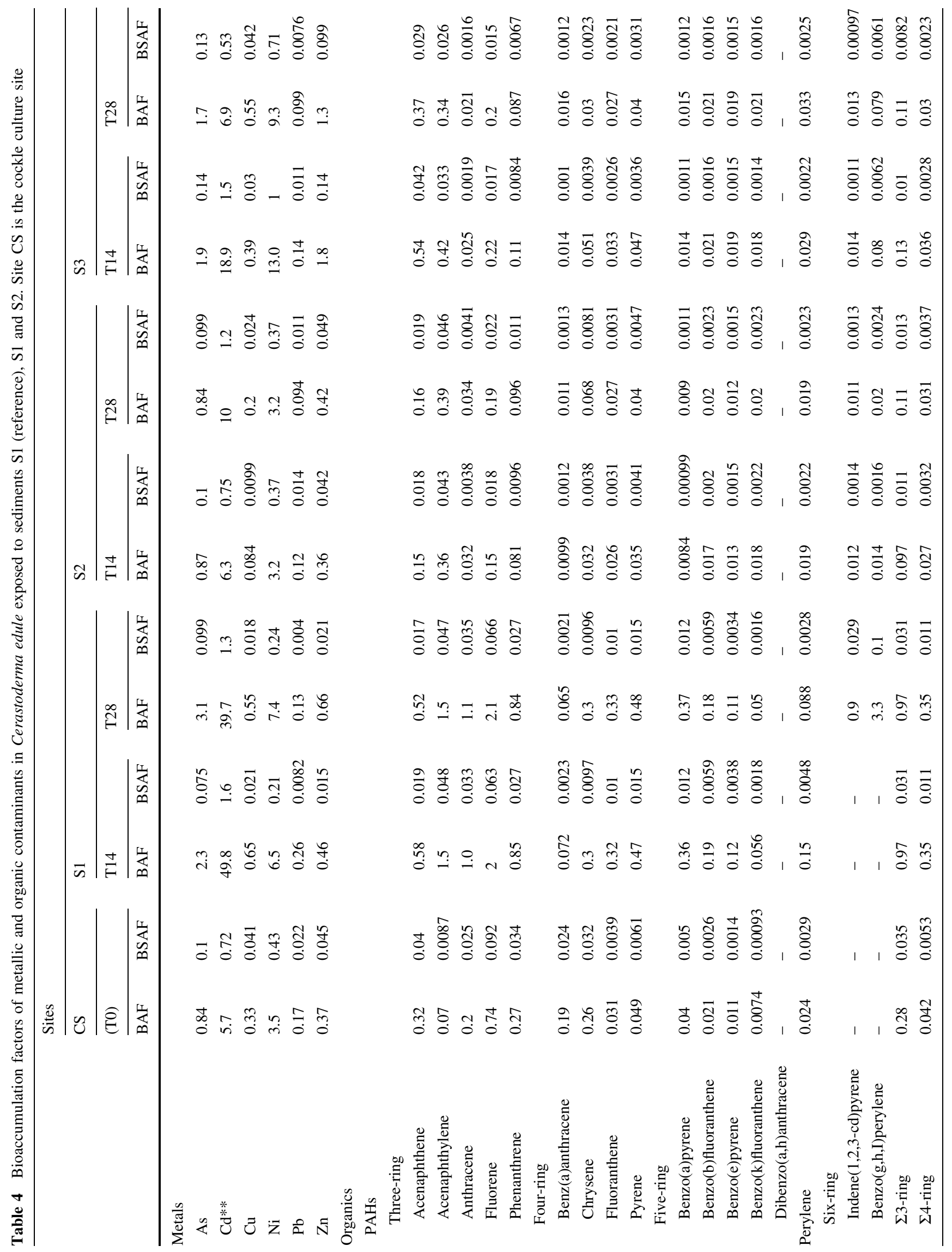




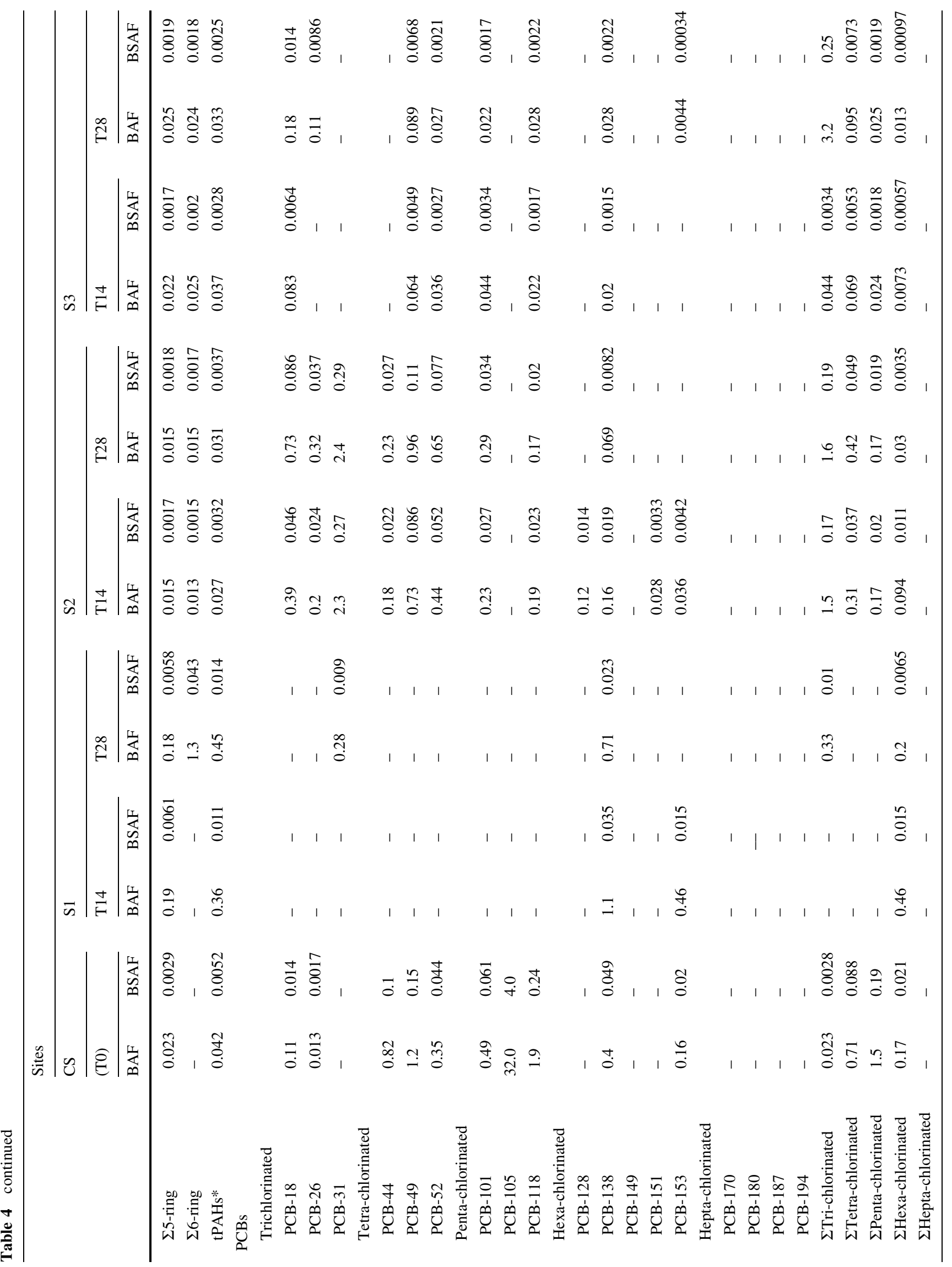




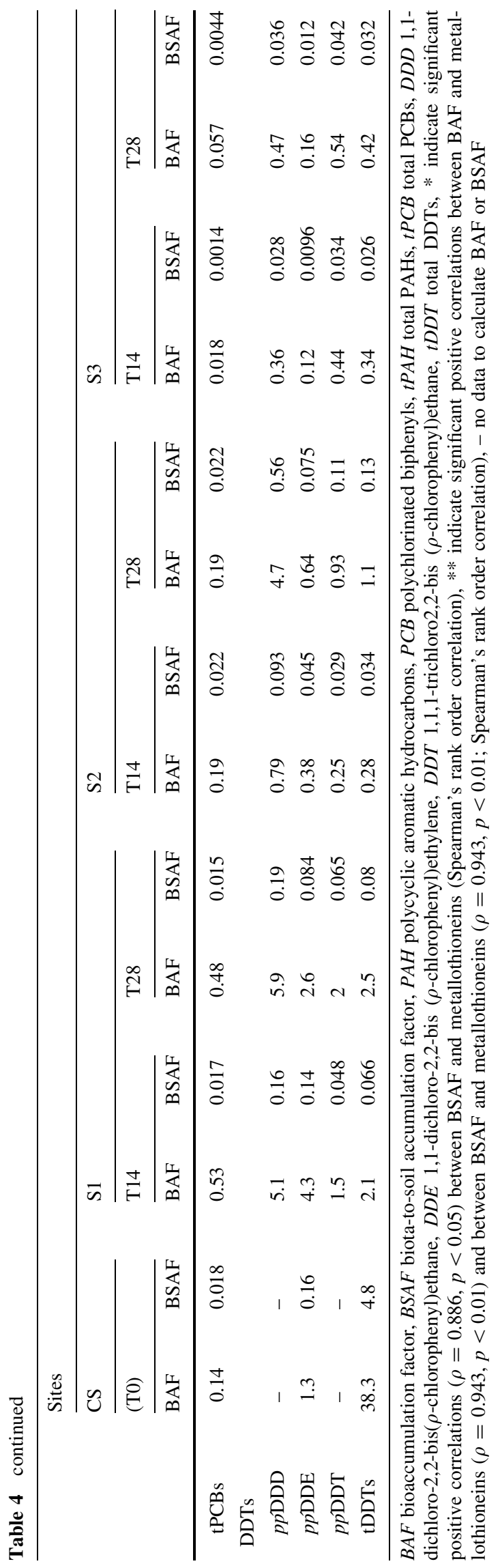

and DDTs. The concentration of PAHs in the reference sediment was lower than in other sediments and therefore, BAFs for PAHs were much higher. BAF of DDTs in the culture sediment was observed to be higher although the concentration of DDTs in this sediment was very low. BAFs were more elevated for $\mathrm{Cd}$ and $\mathrm{Ni}(>>1)$ and DDTs (usually $>1$ ). In general, regarding metals, BSAF values were always lower for animals exposed to the reference sediment (except for $\mathrm{Cd}$ ) and, for organic contaminants, were always lower in sediment S3. These results, however, may be explained by factors influencing bioavailability. Theoretically, if the bioavailability of contaminants depends only on the existence of a strong correlation between contaminant concentration and TOM, BSAF should be constant but the BSAF values obtained were very variable. It must be noted, though, that some variability found in BSAF values may be explained by the different quality of organic matter contents, sorption behaviour and other physico-chemical parameters affecting the bioavailability of contaminants (see Du Laing et al. 2009, for a review). Variable BSAFs have also been found in landworms exposed to pesticides (Jantunen et al. 2008) and for cadmium and BDE-99 (a polybrominated flame retardant) in Baltic Sea benthic invertebrates (Thorsson et al. 2008). The positive correlations between BAF and BSAF of $\mathrm{Cd}$ and MT may indicate that cockles respond not only to the concentration of bioaccumulated $\mathrm{Cd}$ but also to the relationship between the concentration of $\mathrm{Cd}$ in the organism and that in the sediment, i.e. the concentration at which they are exposed. This was also verified in a study with arsenic in another bivalve, Corbicula fluminea (Costa et al. 2009). The positive correlations between BSAF of PAHs and MT are probably related with MT induction by oxidative radicals produced resulting from PAH catabolism (e.g. Buico et al. 2008). However, it should be noted that a considerable decrease was observed in tPAH accumulated in S3-exposed bivalves when compared to the animals exposed to the reference sediment. This difference might be related to higher PAH catabolism triggered by increased concentrations of bioavailable PAH. If a higher PAH degradation occurred the very toxic activated forms of PAHs and the oxidative by-products likely explain the very considerable increase in histopathological damage observed for S3-exposed bivalves at T28.

The time-of-exposure factor is known to be crucial for the bioaccumulation of contaminants. Cockles may need an adaptation period to reach the limit of accumulation in relation to the concentration in the sediment, after which a plateau stage in accumulation (under steady-state conditions) is reached (see Luoma and Rainbow 2005, for a review). This might be reflected in the general evaluation of BAFs for all sediments: while the sediment S1 (reference) is the least contaminated (SQG-Q $=0.082$ ) and has, 

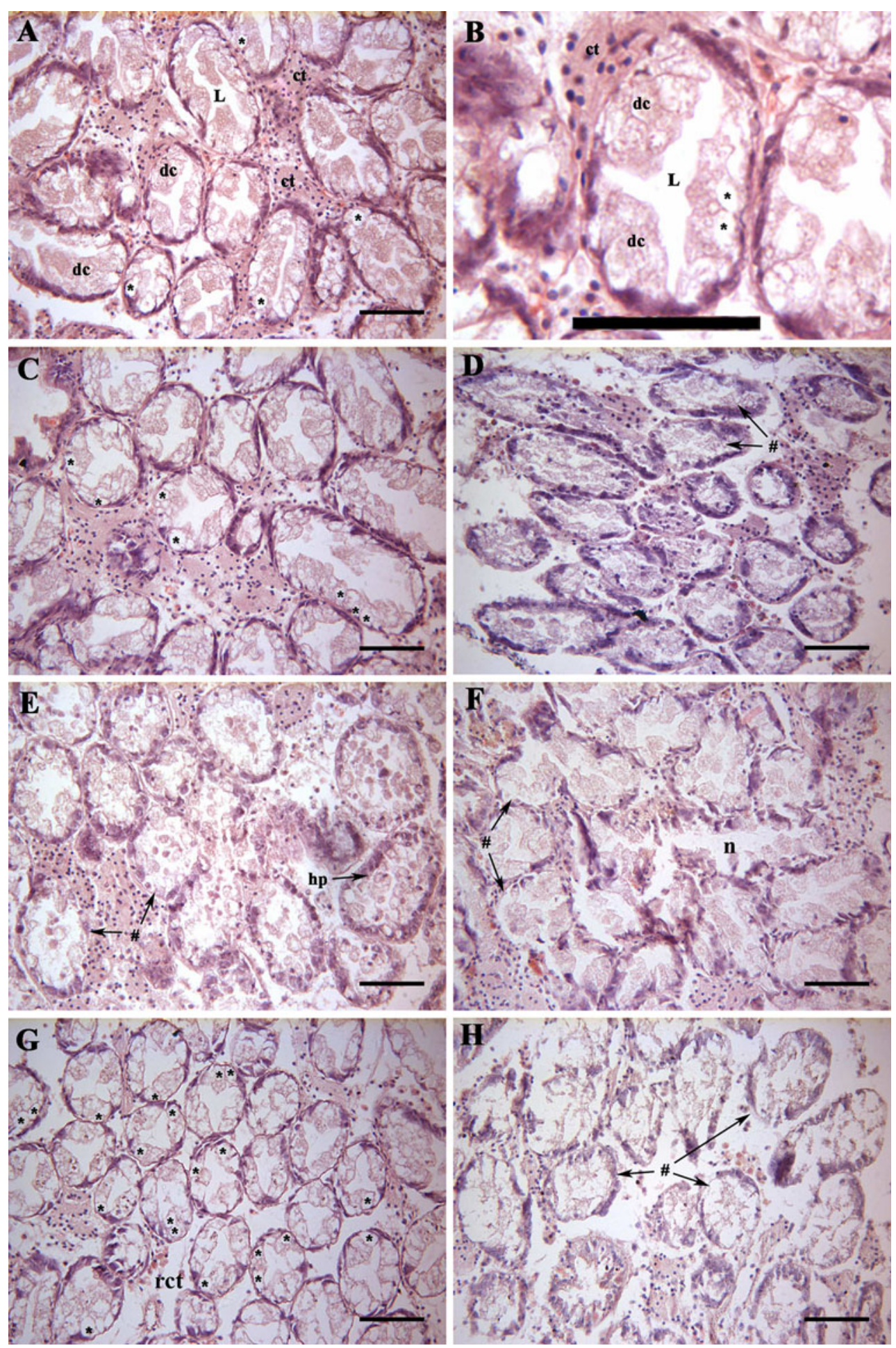

in general, higher BAFs, the sediment $\mathrm{S} 2$ is the most contaminated (SQG-Q $=0.313$ ) and has generally the lowest BAFs. Interestingly, the sediment where the cockles were cultured (CS) was found to be the second most contaminated (SQG-Q $=0.181$ ) but the BAFs estimated for T0 animals, which basically reflect the culture sediment's conditions, are often slightly lower than those of the animals exposed to the reference sediment. It is likely that the cockles from sediment CS were exposed to local contamination throughout their lives and it is possible that the steady-state could be attained between the levels of contaminants in the distinct compartments of the ecosystem. 
4 Fig. 2 Histological sections stained with haematoxylin and eosin of digestive gland of Cerastoderma edule. Scale bar: $50 \mu \mathrm{m}$. A T0 cockle showing a normal digestive gland, with connective tissue $(c t)$ between tubules. The tubules present a normal structure, with a welldefined lumen $(L)$. Digestive cells $(d c)$ and excretory cells (*) in tubule walls are clearly visible. B Enlargement of image A showing a digestive gland tubule, where the lumen $(L)$ and connective tissue $(c t)$ are intact, and the digestive cells $(d c)$ and excretory cells (*) are easily distinguished. C Digestive gland from a cockle exposed to the reference sediment $(S 1)$ for 14 days. The number of excretory cells (*) increased but the digestive gland remains unaltered. D Digestive gland of a cockle exposed to the reference sediment (S1) for 28 days, exhibiting connective tissue regression and tubules with altered and disaggregating epithelial cells (\#). E Cockle exposed to sediment from site $S 2$ (the most contaminated), collected at T14. There is a marked degradation of the digestive gland integrity, with the tubule cells detaching from the basal lamina (\#). Moderate regression of intertubular connective tissue can also be observed. Hyperplasia of tubule epithelial cells was found to be a recurrent alteration $(h p)$. F Digestive gland of a cockle exposed to sediment $S 2$ at T28. Although the regression of connective tissue remains moderate, tubule regression becomes more severe, loosing their shape and exhibiting many cells detaching to the lumen (\#) and occasional foci of necrosis $(n)$. G Cockle exposed to sediment $S 3$ at T14. The epithelium of tubules is essentially intact but a major loss of the surrounding connective tissue can be observed. The number of tubule excretory cells increased compared to T0 individuals (\#) and a very considerable regression of connective tissue $(r c t)$ can be observed. H Cockle exposed to sediment $S 3$ for 28 days, exhibiting a pronounced degradation in the digestive gland, affecting tubule integrity (with very pronounced detachment of cells to the lumen (\#) and the connective tissue

Nevertheless, although SQG-Qs, could be used as indicators of toxicity, it might be inferred that they should not be considered on their own. These guidelines are based on xenobiotics concentrations, not taking into account the bioavailability of contaminants (unlike bioaccumulation data) or the synergetic/antagonistic effects of contaminants.

The qualitative approach to assess histopathological alterations permitted the identification of alterations to the digestive glands consistent with the levels of sediment contamination. However, further research is needed to assess the causes and full biological significance of these potential biomarkers and attempts are made to enforce some sort of semi-qualitative approach. Exposure to sediments caused more damage in digestive glands of cockles exposed to the most contaminated sediments, S2 and S3 when compared to the exposure to the reference sediment and the severity of the histopathological lesions was observed to be progressive from T0 to T28. Nevertheless, it is likely that unaccounted factors during the assays and variables influencing the release of xenobiotics from the sediments have contributed to the increase of digestive gland alterations in cockles exposed to the reference sediment, affecting the animals especially at a later stage of the assay. The moderate increase of the number of excretory cells in cockles exposed to the reference sediment (S1) at day 14 (Fig. 2C) could be due to the low level of contaminants $(\mathrm{SQG}-\mathrm{Q}<0.1)$ but at day 28 the excretory cells are rarely identified due to the presence of severe lesions. Decrease of connective tissue and disaggregation and unidentified cells were presented (Fig. 2D). These damages do not appear to be caused by the contaminants, since this sediment is overall little contaminated by any of the surveyed classes of toxicant, unless unknown chemicals were present in this sediment, or due to the sediment's low TOM and FF, thus increasing bioavailability (Eggleton and Thomas 2004). However, it should be noticed that it has been verified that metal exposure enhances excretory activity in the digestive cells of molluscs and increases the number of excretory cells (Zaldibar et al. 2008). The noticeably increased number of excretory cells in the digestive glands' tubules of cockles exposed to sediment S3 for 14 days (Fig. 2G) might be linked to sediment contamination (probably as a defence mechanism linked to the elimination of xenobiotics, their metabolites or any cellular metabolites resulting from toxicity). At day 28, the damage observed consisted mostly of loss of epithelial tissue structure and epithelial lifting from tubule basal laminae (Fig. 2H). There was an evident degradation in the digestive gland tubule integrity, so the excretory cells are hardly identified. In cockles exposed to sediments S2 and S3, histological damage was very pronounced at T14 and, especially, T28, which is in general accordance with the highest contamination observed for these sediments.

Induction of MT is usually related to exposure to metals and metalloids. However, these elements are not the only factors that modulate MT. For example, in a study with Corbicula fluminea, MT transcription was positively linked to the increasing metabolic activity related to the seasonal temperature elevations (Bigot et al. 2009). In another example regarding $C$. edule, it is suggested that even parasites can modulate MT synthesis and consequently interfere with the response of these protective proteins in case of metal contamination (Baudrimont et al. 2006). The present study showed a decrease of MT levels in cockles exposed to sediment S3. However, positive correlations were obtained between PAH, BSAFs and MT and between Cd BSAFs and Cd BAFs and MT, which is in general accordance with the known high inducibility of MT by this metal (e.g. Marie et al. 2006). On the other hand, the positive correlation between bioaccumulation factors for Cd to MT suggests that MT induction is highly dependent on the availability of strong MT inducers (like Cd), which adds up to yet another factor contributing to the variability in MT responses, as suggested by other surveys (e.g. Costa et al. 2008). The reduction in MT contents, conversely may partially explained by the complex effects of contaminant interactions. PAHs, for instance, found in the tested sediments, have been found to suppress MT biosynthesis even in the presence of strong metal inducers (Risso-De 
Faverney et al. 2000). It should also not be discarded that gene expression and protein synthesis is impaired in tissue damage by exposure to toxicants, as histologically determined the digestive glands of the cockles exposed to the most contaminated sediments.

This study revealed notable responses in cockles to different levels of contamination, hence, it is suggested that C. edule responds to sediment-bound contamination. For some contaminants, bioaccumulation decreased, which can be due to the observed deterioration of digestive gland tissue and subsequent impairment of responses to xenobiotics. Still, the species revealed to be robust to endure both the contamination profiles and the testing procedures. Bioaccumulation and histopathology were successfully integrated and provided valuable information of what happens in estuarine sediments even when complex interaction of different types of contaminants is involved. Therefore, this cockle might be suitable for biomonitoring, even though it is clear that the effects of contaminant interactions on biomarkers and indicators of exposure need yet much research. These include further development on the histopathological biomarkers here qualitatively screened in the digestive gland such as deterioration of tubules, excretory cell alterations, epithelia and connective tissue and detachment of tubular epithelia. On the other hand, it must be noticed that caution is mandatory when testing bivalves cultured in natural sediments since the levels of contaminants of the culture sediments are likely capable of influencing the results, as suspected from the present study.

Acknowledgments The present research was approved by the Portuguese Science and Technology Foundation (FCT) and POCTI (Programa Operacional Ciência, Tecnologia e Inovação, research project ref. POCTI/AMB 57281/104) and financed by FEDER (European Fund for Regional Development). The authors would also like to thank APSS (Administração dos Portos de Setúbal e Sesimbra, SA) and RNES (Reserva Natural do Estuário do Sado) for the logistic support and Mr Manuel Ribeiro for the offer of the cockles.

\section{References}

Amiard J-C, Amiard-Triquet C, Barka S, Pellerin J, Rainbow PS (2006) Metallothioneins in aquatic invertebrates: their role in metal detoxification and their use as biomarkers. Aquat Toxicol 76:160-202

Baudrimont M, de Montaudouin X, Palvadeau A (2006) Impact of digenean parasite infection on metallothionein synthesis by the cockle (Cerastoderma edule): a multivariate field monitoring. Mar Pollut Bull 52:494-502

Bergayou H, Mouneyrac C, Pellerin J, Moukrim A (2009) Oxidative stress responses in bivalves (Scrobicularia plana, Cerastoderma edule) from the Oued Souss estuary (Morocco). Ecotox Environ Safe 72:765-769

Bigot A, Doyen P, Vasseur P, Rodius F (2009) Metallothionein coding sequence identification and seasonal mRNA expression of detoxification genes in the bivalve Corbicula fluminea. Ecotox Environ Safe 72:382-387

Buico A, Cassino C, Dondero F, Vergani L, Osella D (2008) Radical scavenging metallothionein isoforms: an ESR study. J Inorg Biochem 102:921-927

Caeiro S, Costa MH, Ramos TB, Fernandes F, Silveira N, Coimbra A, Medeiros G, Painho M (2005) Assessing heavy metal contamination in Sado Estuary sediment: an index analysis approach. Ecol Indic 5:151-169

Caetano M, Fonseca N, Cesário R, Vale C (2007) Mobility of Pb in salt marshes recorded by total content and stable isotopic signature. Sci Total Environ 380:84-92

Cajaraville MP, Bebianno MJ, Blasco J, Porte C, Sarasquete C, Viarengo A (2000) The use of biomarkers to assess the impact of pollution in coastal environments of the Iberian Peninsula: a practical approach. Sci Total Environ 247:295-311

Clesceri LS, Greenberg AE, Eaton AD (1999) Standard methods for examination of water \& wastewater, 20th edn. American Public Health Association, Baltimore

Cortesão C, Vale C (1995) Metals in sediments of the Sado Estuary, Portugal. Mar Pollut Bull 30:34-37

Costa PM, Repolho T, Caeiro S, Diniz ME, Moura I, Costa MH (2008) Modelling metallothionein induction in the liver of Sparus aurata exposed to metal-contaminated estuarine sediments. Ecotox Environ Safe 71:117-124

Costa PM, Santos HM, Peres I, Costa MH, Alves S, Capelo-Martinez JL, Diniz MS (2009) Toxicokinetics of waterborne trivalent arsenic in the freshwater bivalve Corbicula fluminea. Arch Environ Con Tox 57:338-347

De Kock WC, Kramer KJM (1994) Active biomonitoring (ABM) by translocation of bivalve molluscs. In: Kramer KJM (ed) Biomonitoring of coastal waters and estuaries. CRC Press, Boca Raton, pp 51-84

Del Valls TA, Forja JM, Gómez-Parra A (1998) The use of multivariate analysis to link sediment contamination and toxicity data to establish sediment quality guidelines: an example in the Gulf of Cádiz (Spain). Cienc Mar 24:127-154

Diniz M, Santos HM, Costa PM, Peres I, Costa MH, Capelo JL (2007) Metallothionein responses in the Asiatic clam (Corbicula fluminea) after exposure to trivalent arsenic. Biomarkers 12:589-598

Du Laing G, Rinklebe J, Vandecasteele B, Meers E, Tack FMG (2009) Trace metal behaviour in estuarine and riverine floodplain soils and sediments: a review. Sci Total Environ 407:3972-3985

Eggleton J, Thomas KV (2004) A review of factors affecting the release and bioavailability of contaminants during sediment disturbance events. Environ Int 30:973-980

Ferreira AM, Martins M, Vale C (2003) Influence of diffuse sources on levels and distribution of polychlorinated biphenyls in the Guadiana River estuary, Portugal. Mar Chem 89:175-184

Geret F, Serafim A, Bebianno MJ (2003) Antioxidant enzyme activities, metallothioneins and lipid peroxidation as biomarkers in Ruditapes decussatus. Ecotoxicology 12:417-426

Gold-Bouchot G, Simá-Alvarez R, Zapata-Pérez O, Guemez-Ricalde J (1995) Histopathological effects of petroleum hydrocarbons and heavy metals on the American oyster (Crassostrea virginica) from Tabasco, México. Mar Pollut Bull 31:4-12

Hédouin L, Pringault O, Metian M, Bustamante P, Warnau M (2007) Nickel bioaccumulation in bivalves from the New Caledonia lagoon: seawater and food exposure. Chemosphere 66:1449-1457

Huggett RJ, Kimerle RA, Mehrle PM, Bergman HL (eds) (1992) Biomarkers: biochemical, physiological, and histological markers of anthropogenic stress. Lewis Publishers, Boca Raton, FL 
Jantunen APK, Tuikka A, Akkanen J, Kukkonen JVK (2008) Bioaccumulation of atrazine and chlorpyrifos to Lumbriculus variegatus from lake sediments. Ecotox Environ Safe 71:860-868

Jung K, Stelzenmüller V, Zauke G-P (2006) Spatial distribution of heavy metal concentrations and biomass indices in Cerastoderma edule Linnaeus (1758) from the German Wadden Sea: an integrated biomonitoring approach. J Exp Mar Biol Ecol 338:81-95

Lee H (1992) Models, muddles, and mud: predicting bioaccumulation of sediment associated pollutants. In: Burton AG (ed) Sediment toxicity assessment. CRC, Boca Raton, FL, pp 267-293

Livingstone DR (2001) Contaminant-stimulated reactive oxygen species production and oxidative damage in aquatic organisms. Mar Pollut Bull 42(8):656-666

Long ER, MacDonald DD (1998) Recommended uses of empirically derived, sediment quality guidelines for marine and estuarine ecosystems. Hum Ecol Risk Assess 4:1019-1039

Luoma S, Rainbow P (2005) Why is metal bioaccumulation so variable? Biodynamics as a unifying concept. Environ Sci Technol 39:1921-1931

MacDonald DD, Carr S, Calder F, Long E, Ingersoll C (1996) Development and evaluation of sediment quality guidelines for Florida coastal waters. Ecotoxicology 5:253-278

MacDonald DD, Carr RS, Eckenrod D, Greening H, Grabe S, Ingersoll CG, Janicki S, Janicki T, Lindskoog RA, Long ER, Pribble R, Sloane G, Smorong DE (2004) Development, evaluation, and application of sediment quality targets for assessing and managing contaminated sediments in Tampa Bay, Florida. Arch Environ Cont Tox 46:147-161

Machreki-Ajmi M, Ketata I, Ladhar-Chaabouni R, Hamza-Chaffai A (2008) The effect of in situ cadmium contamination on some biomarkers in Cerastoderma glaucum. Ecotoxicology 17:1-11

Marie V, Baudrimont M, Boudou A (2006) Cadmium and zinc bioaccumulation and metallothionein response in two freshwater bivalves (Corbicula fluminea and Dreissena polymorpha) transplanted along a polymetallic gradient. Chemosphere 65:609-617

Martins M, Ferreira AM, Vale C (2008) The influence of Sarcocornia fruticosa on retention of PAHs in salt marshes sediments (Sado estuary, Portugal). Chemosphere 71:1599-1606
Martoja R, Martoja M (1967) Initiation aux tecniques de l'histologie animal. Masson \& Cie, Paris, p 345

Peakall DB, Shugart LR (eds) (1993) Biomarkers research and application in the assessment of environmental health. SpringerVerlag, Berlin, Heidelberg

Risso-de Faverney C, Lafaurie M, Girard J-P, Rahmani R (2000) Effects of heavy metals and 3-methylcholanthrene on expression and induction of CYP1A1 and metallothionein levels in trout (Oncorhynchus mykiss) hepatocyte cultures. Environ Toxicol Chem 19:2239-2248

Serafim A, Bebianno MJ (2009) Metallothionein role in the kinetic model of copper accumulation and elimination in the clam Ruditapes decussates. Environ Res 109:390-399

Solé M, Kopecka-Pilarczyk J, Blasco J (2009) Pollution biomarkers in two estuarine invertebrates, Nereis diversicolor and Scrobicularia plana, from a Marsh ecosystem in SW Spain. Environ Int 35:523-531

Syasina IG, Vaschenko MA, Zhadan PM (1997) Morphological alterations in the digestive diverticula of Mizuhopecten yessoensis (Bivalvia: Pectinidae) from polluted areas of Peter the Great Bay, Sea of Japan. Mar Environ Res 44:85-98

Thorsson MH, Hedman JE, Bradshaw C, Gunnarsson JS, Gilek M (2008) Effects of settling organic matter on the bioaccumulation of cadmium and BDE-99 by Baltic Sea benthic invertebrates. Mar Environ Res 65:264-281

United States Environmental Protection Agency (1995) CRITFC exposure study. Water quality criteria and standards Newsletter. USEPA, Washington, DC

Zaldibar B, Cancio I, Soto M, Marigómez I (2007) Digestive cell turnover in digestive gland epithelium of slugs experimentally exposed to a mixture of cadmium and kerosene. Chemosphere 70:144-154

Zaldibar B, Cancio I, Soto M, Marigómez I (2008) Changes in celltype composition in digestive gland of slugs and its influence in biomarkers following transplantation between a relatively unpolluted and a chronically metal-polluted site. Environ Pollut 156:367-379 